\title{
The Role of GAD65 Autoantibodies in the development of Type-1 Diabetes
}

\author{
Sri R. Prasetyo \\ Departemen Biomedik Dasar Universitas Kristen Indonesia
}

\begin{abstract}
The finding of the autoantibodies to islet cells (ICAs) in type-1 diabetes patients is important for developing the fine tuning of individualized therapy. Antibody to Glutamate decarboxylase 2 (GAD65Ab) is the most reliable sign, since it has the most stable sensitivity as diagnostic tool for detecting type-1diabetes. As a key enzyme in gamma-Aminobutyric acid (GABA) synthesis, GAD65 damage caused by GAD65 antibodies (GAD65Abs) would lead to decrease in the amount of GABA vesicles released by $\beta$-cells. Decrease of GAD65 induced by GAD65Ab may endanger the paracrine or autocrine function of GABA, that mediated by $\gamma$-aminobutyric acid type $A$ receptors $\left(\mathrm{GABA}_{\mathrm{A}} \mathrm{R}\right)$ would depolarized the $\beta$-cells. The depolarization then increases intracellular $\mathrm{Calsium}\left(\mathrm{Ca}^{2+}\right)$ concentration that is needed for insulin release. The effect of GABA on $\beta$-cells is also important for proliferation and anti-apoptosis of $\beta$-cells. Moreover, decrease in GABA release also impairs the inhibiting effect of GABA on T-cell proliferation and inflammatory cytokines release that may end up with escalation of GAD65 damage.
\end{abstract}

Keywords: Type-1 diabetes, autoantibody, GAD65

\section{Peran Autoantibodi GAD65 dalam Perkembangan Diabetes Tipe-1}

\begin{abstract}
Penemuan autoantibodi terhadap sel pulau atau islet cells (ICA) pada pasien diabetes tipe-1 penting untuk mengembangkan penyesuaian terapi individual. Antibodi terhadap Glutamat dekarboksilase 2 (GAD65Ab) adalah tanda yang paling dapat diandalkan, karena memiliki sensitivitas yang paling stabil sebagai alat diagnostik untuk mendeteksi diabetes tipe-1. Sebagai enzim kunci dalam sintesis asam gamma-aminobutirat (GABA), kerusakan GAD65 yang disebabkan oleh antibodi GAD65 (GAD65Abs) akan menyebabkan penurunan jumlah vesikel GABA yang dilepaskan oleh sel. Penurunan GAD65 yang diinduksi oleh GAD65Ab dapat membahayakan fungsi parakrin atau autokrin GABA, yang dimediasi oleh reseptor asam $\gamma$-aminobutirat tipe $\mathrm{A}\left(\mathrm{GABA}_{\mathrm{A}} \mathrm{R}\right)$ akan mendepolarisasi sel. Depolarisasi kemudian meningkatkan konsentrasi kalsium $\left(\mathrm{Ca}^{2+}\right)$ intraseluler yang diperlukan untuk pelepasan insulin. Efek GABA pada sel beta juga penting untuk proliferasi dan anti-apoptosis sel beta. Selain itu, penurunan pelepasan GABA juga merusak efek penghambatan GABA pada proliferasi sel T dan pelepasan sitokin inflamasi yang mungkin berakhir dengan peningkatan kerusakan GAD65.
\end{abstract}

Kata kunci: Diabetes tipe-1, autoantibodi, GAD65

SRP: Penulis Koresponden; E-mai: djeki.pras@gmail.com 


\section{Introduction}

Characterization of type- 1 diabetes has been developed, and mainly includes several autoantibodies related to $\beta$-cells demise. The finding of the autoantibodies has become an important study for individualized therapy. ${ }^{1}$ Recently, the antibodies is used in recommendation for research in type-1 diabetes. ${ }^{1}$

Antibodies to islet cells (ICAs) in type1 diabetes targets the autoantigens GAD65 (GAD65Ab), IA-2 (IA-2Ab), or insulin (IAA). ${ }^{2}$ Studies conclude that the number of autoantibodies is more predictive than their order of appearance. Expression of IA- $2 \mathrm{Ab}$ and IAA is affected by age and sex - it decreases with increasing age, 50$60 \%$ below the age of 10 years. GAD65Ab appears to be more steady compared to IA- $2 \mathrm{Ab}$ and IAAs, since the diagnostic sensitivity remain $70-80 \%$ regardless of age. ${ }^{2}$ Proven that antibody to GAD65 has the most stable diagnostic sensitivity ${ }^{2}$, the mechanism of how GAD65 $\mathrm{Ab}$ affects the function of islets cells, especially $\beta$-cells, is of important matter to be elucidated.

\section{Type 1 Diabetes and Diabetic Autoantibodies}

Type 1 diabetes (T1D) is a type of diabetes mellitus that is caused by autoimmune- $\beta$ cell destruction. ${ }^{1}$ Former paradigm of T1D is that it occurs only in children, but the fact is that T1D occurs in all ages. ${ }^{1}$ Recommendation for diagnosing T1D includes: 1. Plasma blood glucose (rather than A1C), in order to identify the acute onset of T1D; 2. Panel of autoantibodies (currently is recommended in clinical research setting); 3. Based on clinical research setting, the persistence of two or more autoantibodies could predict the existence of T1D that may need intervention. ${ }^{1}$

The autoantibodies that relate to T1D and become autoimmune marker of the disease are autoantibodies to GAD (GAD65), insulin, tyrosine phosphatase IA-2 and IA$2 \beta$, and ZnT8. ${ }^{2}$ Tyrosine phosphatase IA-2 and IA- $2 \beta$ are transmembrane proteins that play an important role in the secretory pathway of endocrine cells ${ }^{3}$, while ZnT8 is a zinc transporter expressed predominately in pancreatic $\alpha$ and $\beta$ cells ${ }^{4}$. The event associated with the formation of the autoantibodies has not been elaborated yet. It is assumed that the autoantigens are shed from the pancreatic islet, and taken up by the circulating macrophages or dendritic cells that may migrate to lymph nodes resulting in antigen presentation that may lead to autoantibodies production. The firstly produced autoantibodies might alter the following autoantigen processing and presentation by class II major histocompatibility complexes. Further more, the alteration may increase the efficiency of antigen capture by antigenspecific $\beta$-cell receptors, and/or Fc receptors on monocytes, macrophages, and dendritic cells. Efficiency in antigen capture would lower the threshold for T-cell response. ${ }^{2}$ Several experiments demonstrated that presence of autoantibodies could enhance or shift the T-cell response to autoantigens. The potential role of the autoantibodies has raised the hypothesis proposing that antibody-mediated antigen internalization may result in changes of the T-cell response to autoantigens, and further more could lead to autoimmune diseases. ${ }^{2}$

Based on a U.S. study, the Diabetes Prevention Trial (DPT-1), the antibody to GAD65 (GAD65Ab) is the most sensitive marker for detecting T1D antibody positivity. In the study, $91 \%$ of individuals with GAD65ab positive were also positive for other antibodies, compared to the antibodies to Islet cells ( $82 \%$ individuals). Therefore, GAD65ab is the most important antibody in the antibody screening paradigm for evaluating T1D suspected individuals. ${ }^{2}$ 


\section{GAD65 Function}

Glutamate decarboxylase is the enzyme involved in the synthesis of gamma-aminobutyric acid (GABA), a major transmitter of the central nervous system. ${ }^{5}$ It is also found in the pancreatic $\beta$-cells and functions in the conversion of glutamic acid into GABA. ${ }^{6}$ In neurons, GAD65 is found localized at the terminal ends, and functions in the release of GABA containing vesicles. ${ }^{7}$ In pancreatic islet cells, synaptic-like microvesicles were found in $\beta$-cells and $\beta$-cell line that have neurite-like processes. The vesicles were concentrated in the distal portion of the processes. The GAD65 was found also to be localized around the vesicles (similar to the localization of GAD around synaptic vesicles in GABA secreting neurons). ${ }^{6}$

\section{$G A D 65$ and the release of $G A B A$}

The mechanism of GABA release related to GAD65 was studied in the context of the inhibitory function of inhibitory synapses in the CNS. GAD65 together with other isoform the GAD67 are suggested to have distinct role in neuronal function. While GAD67 is a cytosolic enzyme and distributed throughout the cell, GAD65 is localized to the nerve terminals and is bound reversibly to the membrane of synaptic vesicles. These finding suggests that the function of GAD65 is specific, which is to release GABA from the synaptic terminals. Study in mice in which the GAD65 was disrupted showed that the mice became susceptible to seizures. ${ }^{5}$

Factors that control the amount and packaging of GABA in synaptic vesicles are not well understood, but it is known that the GADs are responsible for the synthesis of GABA. Study on inhibitory synapses of the retina and hippocampus of GAD65 lacking mice showed that the basal inhibitory postsynaptic currents was normal, but sustained stimulation caused defect in transmitter release. The study concluded that in retina and hippocampus of GAD65 lacking mice, the primary defect is the vesicle release. ${ }^{7}$

\section{Pancreatic GAD65}

The existence of pancreatic GAD65 is found related to the finding of "synapticlike microvesicles" (SLMVs) in pancreatic $\beta$-cells, and share the same function and mechanism of release with the vesicles in neurons. GAD65 was found around the SLMvs of $\beta$-cells using electron microscopy immunogold labeling of pancreatic islets and by immunofluorescence on $\beta$-cell line. However, studies using subcellular fractionation still could not demonstrate direct association between GAD65 and vesicle membrane. $^{8}$

\section{$G A B A$ and insulin secretion}

It has been known that pancreatic $\beta$-cells also produce large amount of GABA that is stored in SLMVs, and distinctly separated from insulin vesicles - large-dense core vesicles (LDCVs). Recent study found that in human islets, GABA is co-localized with insulin in the LDCVs and the release of GABA from $\beta$-cells is glucose dependent. The release of GABA is "tonic" and is regulated by metabolic state of $\beta$-cells. Expression of GABA receptors $\left(\mathrm{GABA}_{\mathrm{A}} \mathrm{Rs}\right)$ had been demonstrated in primary islet $\beta$-cells and insulin-secreting clonal $\beta$-cells lines. ${ }^{9}$

Study using rat-insulinoma cells, with patch clamp method showed that perfusion of the cell with high glucose extracellular solution lead to depolarization of the cell. Perfusion with GABA also depolarized the cell. The result indicated that GABA induced membrane depolarization, followed by increased of intracellular $\mathrm{Ca}^{2+}$, enhanced insulin secretion in the present of physiological glucose concentration. ${ }^{9}$ 


\section{Autoantibody to GAD65 and type-1 diabetes}

The breakdown of immunological tolerance to the pancreatic $\beta$-cells in type- 1 diabetes may involve modulation of GAD65 presentation to the $\mathrm{T}$ cells by diseaseassociated GAD65Abs. ${ }^{2}$ Fig. 1 describes the action of GABAas paracrine or autocrine. ${ }^{10}$ Glutamate as the precursor of GABA enter the $\beta$-cell by way of glutamate transporter- 1 (GLT-1), then converted to GABA by GAD and packed in the synaptic like micro vesicles (SLMMVs). Released by the cell, the GABA then binds with $\mathrm{GABA}_{\mathrm{A}} \mathrm{R}$ and mediates the responses of the $\beta$-cells that may include insulin release, $\beta$-cell proliferation and anti apoptosis. ${ }^{10}$
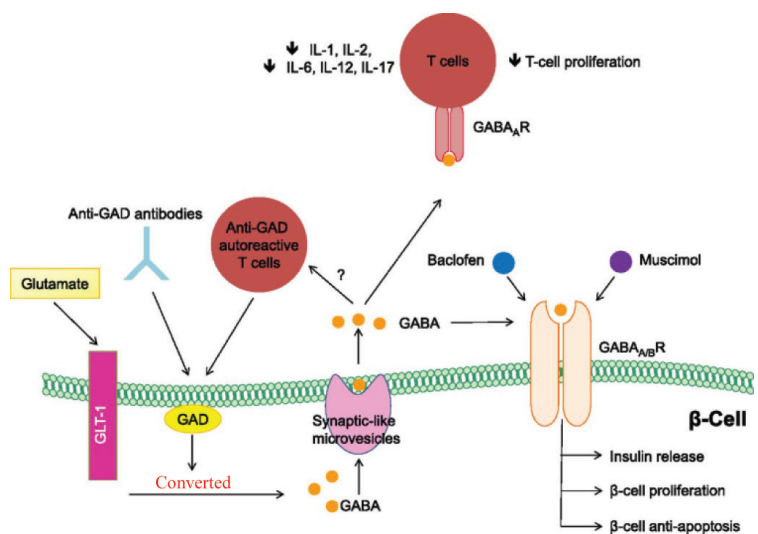

Fig.1. GABA acts as paracrine or autocrine, and the role of GABA in regulating the function of T-cell. ${ }^{10}$ (downloaded from: http://doi.org/10.2337/db13-1243 with modification)

GABA also influences $T$ cells by binding with $\mathrm{GABA}_{\mathrm{A}} \mathrm{R}$ present in T-cell and results in decreased production of inflammatory cytokines and T-cell proliferation. ${ }^{10}$ Existence of anti GAD-antibodies could end up with decrease GABA with the following effects including autoreactive T-cell.

\section{Conclusion}

Type-1 diabetes is characterized by the decrease of insulin secretion. GAD65 Abs is found to become important for predicting the development of Type-1 diabetes. The existence of DAAs especially GAD65Ab could lead to damage of GAD65 that is important for GABA release from pancreatic $\beta$-cells. Thus, damage of GAD65 by GAD65Abs would lead to the decrease function of humoral reflex arch involving GABA- GABA ${ }_{A}$ Rs-insulin in $\beta$-cells, and may result in dysfunction or demise of $\beta$-cells. GAD65 damage could be escalated by the decrease of GABA release by way of the decrease of inhibiting effect of GABA on T-cell proliferation and inflammatory cytokine secretion.

\section{References}

1. Classification and Diagnosis of Diabetes: Standards of Medical care in Diabetes - 2018. Diabetes Care 2018, 41(suppl 1): 513-27.

2. Pihoker C, Gilliam LK, Hampe CS, Lernmark E. Autoantibodies in diabetes. Diabetes 2005; 54(suppl 2): 52-61.

3. Torri S. Expression and Function of IA-2 Family Proteins, Unique Neuroendocrine-specific Protein-tyrosine Phosphatases. Endocr J; 2009; 56(5): 639-48

4. Huang Q, Du J, Merriman C, Gong Z. Genetic, Functional, and Immunological Study of ZnT8 in Diabetes. Hindawi Int J Endocrinol; Volume 2019; Article ID 1524905: 1-11

5. Kruger C, Stocker W, Schloser M. Glutamic acid autoantibodies. Autoantibodies $2^{\text {nd }}$ ed 2007: 369-78.

6. Crotti C, Selmi C. Glutamic acid decarboxylase antibody. Autoantibodies $3^{\text {rd }}$ ed 2014: 369-389.

7. Tian N, Peterson C, Kash S, Baekkeskov S, Copenhagen D, Nicoll R. The role of synthetic enzyme GAD65 in the control of neuronal $\gamma$-aminobutyric acid release. PNAS 1999, 22: 12911-12916.

8. Reetz A, Solimena M, Metteoli M, Folli F, Takei K, De Camilli P. GABA and pancreatic $\beta$-cells: colocallization of glutamic acid decarboxylase (GAD) and GABA with synaptic-like microvesicles suggests their role in GABA storage and secretion. EMBO J; 1991, 10: 1275-85.

9. Bansal P, Wang S, Liu S, Xiang Y, Lu W, wang Q. GABA coordinates with insulin in regulating secretory function in pancreatic INS-1 B-cells. PLoS ONE 2011, 10: 1-9

10. Paolo F: GABAergic System in $\beta$-cells. From Autoimmunity Target to Regeneration Tool. Diabetes Nov 2013, 62: 3674-6. 